Fidei: Jurnal Teologi Sistematika dan Praktika, Vol. 3, No. 2, Des. 2020

\title{
Implikasi Praktis Konsep Anugerah Bagi Orang Percaya Berdasarkan Surat Roma 3:23-24
}

\author{
Jetorius Gulo \\ Sekolah Tinggi Teologi Anugerah Misi Nias Barat, Indonesia \\ Email: jetoriusgulo@ymail.com
}

Diterima: 30 Maret 2020

Direvisi: 11 Oktober 2020

Disetujui: 17 Desember 2020

\begin{abstract}
Abstrak
Konsep pemikiran dan cara pandang sebagai orang percaya harus berfokus pada anugerah/kasih karunia Allah yang diberikan secara cuma-cuma. Keselamatan orang percaya atas karya Tuhan Yesus diatas kayu salib. Anugerah memunyai konsep dasar demikian: "yang memberi tidak berkewajiban, yang menerima tidak mempunyai hak". Sedangkan konsep "perbuatan baik" adalah "manusia mendapatkan sesuatu karena melakukan sesuatu" seperti layaknya seorang pegawai yang diupah bulanan karena melakukan pekerjaannya selama satu bulan. Kalau seseorang mentaati aturan Alkitab, kalau melakukan amalibadah maka orang tersebut akan mendapat pahala, itu adalah konsep "perbuatan baik". Dimana hal tersebut menunjukkan seseorang belum sadar akan arti penebusan itu. Allah yang penuh kasih sayang terhadap manusia. Dia ingin manusia mengasihi Dia, percaya kepada Dia bagaikan seorang Bapa, mengharapkan seluruh keselamatan dan kebahagiaan hanya dari Dia. Kalau Allah mengampuni manusia yang berdosa, menganugerahkan kepada hidup, bahkan hidup kekal, tujuanNya tidak lain ialah supaya dengan penuh kasih dan percaya kembali kepadaNya.
\end{abstract}

Kata-Kata Kunci: Anugerah; Konsep; Orang; Percaya.

\section{Abstract}

The concept of thinking and perspective as a believer must focus on God's free gift / grace. The salvation of believers for the work of the Lord Jesus on the 
cross. Grace has this basic concept: "the one who gives is not obliged, the one who receives has no right". Meanwhile, the concept of "good deeds" is "humans get something for doing something" like an employee who is paid monthly for doing his job for one month. If someone obeys the Bible's rules, if he does acts of worship then that person will get rewarded, that is the concept of "good deeds". Where it shows someone is not aware of the meaning of redemption. God who is full of compassion for humans. He wants people to love Him, trust Him like a Father, expect all salvation and happiness only from Him. If God forgives people who sin, grants them life, even eternal life, His goal is none other than so that lovingly and trusting return to Him.

Keywords: Believe; Concept; Grace; People.

\section{Pendahuluan}

Di dunia modern, ketika belajar banyak hal mencari pengetahuan didalam alam semesta, mendalami realita dan berjuang dengan sekuat tenaga dengan biaya penelitian sangat besar, justru disitu menyadari bahwa masih ada sesuatu yang terlewatkan. Alkitab dengan tegas dan jelas membukakan realita yang eksklusif, yang mungkin agak mengganggu pikiran yaitu, "Semua orang telah berbuat dosa dan telah kehilangan kemuliaan Allah" (Rm. 3:23). Fakta dari pernyataan Paulus tersebut seringkali bukan dimengerti sebagai fakta dan realita yang seharusnya diterima tetapi justru ditolak oleh banyak orang disegala zaman. Padahal pernyataan itu bukan tanpa dasar dan dibangun dengan ide fanatisme. Paulus dalam mengunggkapkan realita ini, ia membangun pernyataan dengan sangat teliti mulai dari konsep umum mengenai dosa dan agar manusia akhirnya sadar.

Dalam Roma pasal 3 bagian awal, Paulus memberitahu tentang orangorang yang percaya pada tuhan tetapi sebenarnya bukan Tuhan Yesus yang adalah Allah yang sejati. Allah yang mereka percayai masih belum jelas konsepnya. Secara asali, manusia itu berdosa, rusak, najis, dan tidak mampu melakukan apapun yang baik. ${ }^{1}$ Paulus mengatakan bahwa percaya kepada-Nya (Tuhan Yesus) bukan berarti tidak ada kemungkinan berdosa lagi karena esensi dosa tidak bergantung pada kepercayaan (agama). Padahal cara berpikir semacam itu kalau tidak dipahami dengan benar maka bisa kecewa dan putus asa didalam keberdosaan, bahkan malah meninggalkan Tuhan.

${ }^{1}$ G. J. Baan, TULIP : Lima Pokok Calvinisme (Surabaya: Momentum, 2017), 5. 
Pada awalnya Allah menciptakan manusia dengan baik adanya, karena manusia diciptakan serupa dengan gambar Allah. gambar dan rupa Allah yang di dalamnya manusia diciptakan juga mencakup apa yang biasa disebut dengan "kebenaran asali" atau secara lebih khusus pengetahuan yang benar, kebenaran dan kesucian. ${ }^{2}$ Akan tetapi, karena kehendak manusia yang memilih sesuatu yang salah di hadapan Allah, ${ }^{3}$ sehingga manusia diusir dari Taman Eden (kejadian ini menunjukkan bahwa Allah yang kudus tidak bias lagi "bersatu" dengan manusia yang sudah tidak kudus) dan jatuh kedalam sebuah kubangan yang kelak dinamakan dosa.

Dosa merupakan masalah terbesar umat manusia, tidak ada seorangpun yang terlepas dari kecenderungan berdosa. Jikalau dosa tidak dibiarkan dalam dunia ini bagaimanakah manusia dapat menyatakan kesetiaannya kepada Allah? Sebab ada dosa, manusia di dalam dunia ini dapat menyatakan kesetiaannya kepada Allah dan keberaniannya untuk melawan dosa itu. ${ }^{4}$ Manusia jatuh dan jatuh terus, maka setelah jatuh sadar atau tidak sadar memiliki masalah yang besar dan tidak menemukan jalan keluar dari dosa tersebut yang memadai. Manusia bergumul dan terus mencari jalan keluar dari dosa-dosanya. Ada orang yang meyakini bahwa dengan berbuat baik, beramal banyak maka dosanya bisa diampuni oleh banyaknya kebaikan yang dilakukan baik untuk diri sendiri maupun untuk orang lain. Ada juga orang yang meyakini bahwa dengan menyakiti diri sendiri sampai kesakitan bahkan sampai berdarah-darah, dianggap itu bisa mengampuni dosanya. Dalam usaha manusia menyelesaikan masalah dosa, pada akhirnya ia kecewa karena dosa semakin menggerogoti dan terus menjatuhkan manusia. Namun, ada juga orang yang tidak peduli lagi terhadap dosa, mereka pasrah dan tidak berdaya lagi melawan dosa, maka mereka terus melakukan dosa dan mengampuni diri sendiri. Orang semacam ini sudah terbiasa dan kebal terhadap dosa, tidak ada lagi rasa bersalah bahkan senang dengan keadaannya yang berdosa. Dengan demikian dapat ditegaskan bahwa sementara manusia tidak harus berdosa, namun ia toh akan berdosa. ${ }^{5}$

Kadang-kadang kecenderungan berdosa itu membuat orang tidak berdaya dan tidak bebas melakukan perlawanan untuk tidak berdosa, disaat itu juga dosa semakin menghimpit dan menyerang manusia. Ketika manusia sudah jatuh,

${ }^{2}$ Louis Berkhof, Teologi Sistematika Vol. 1: Doktrin Allah (Surabaya: Momentum, 2008), 49.

${ }^{3}$ Christoph Barth, Teologi Perjanjian Lama 1 (Jakarta: BPK GunungMulia, 2010), 39.

${ }^{4}$ J.Wesley Brill, Dasar Yang Teguh (Bandung: YKH, 1996), 168.

${ }^{5}$ Iris V Cully, Dinamika Kristen (Jakarta: BPK Gunung Mulia, n.d.), 72. 
maka dosa semakin menyerang supaya manusia tidak bisa bangkit lagi dan terus menerus nyaman dalam dosa.

Dosa begitu kuat menyerang setiap orang dengan berbagai macam cara, disetiap situasi apapun, baik disaat kesulitan maupun disaat senang, setiap orang selalu ada saat dan tempat untuk jatuh. Walaupun pada awalnya seseorang tidak menginginkan untuk berbuat dosa dan berusaha semampunya bahkan memunyai tips-tips tertentu untuk tetap kuat menjaga tingkah laku, memilih teman bergaul, berbicara yang positif, melihat situasi dan kondisi tertentu, dll. Namun, kadangkadang tidak disadari atau disengaja pasti akan gagal, baik itu dari bicaranya, pikirannya dan perilakunya yang bisa menyinggung, menyakiti, dan membuat orang lain tidak nyaman atau mencemarkan nama baik. Apa lagi didalam dunia yang sudah modern ini, kemungkinan dan kecenderungan orang berdosa sangat gampang sekali, misalnya dalam pemakaian dalam alat elektronik (HP atau sejenisnya yang dapat mengakses internet) banyak orang yang masuk dalam dunia maya (facebook, whatsap, instagram dll.), disana orang saling menghina satu sama lain, baik antara pribadi, antar suku, antar agama, dan lain-lain, dengan berbagai kepentingan masing-masing. Ada yang saling membenci bahkan sampai barantam hanya gara-gara masalah sepele, misalnya perbedaan pilihan pilitik, perbedaan suka, perbedaan agama, bahkan hanya gara-gara perbedaan fens artis, pemain bola, pemimpin agama, meskipun itu sesama agama. Dosa begitu nyata dan sangat memengaruhi kehidupan umat manusia.

Permasalahan tentang dosa sangat mengganggu dan menakutkan karena siapapun bisa terjerumus didalamnya, baik orang pintar yang berpendidikan, orang biasa yang tidak berpengaruh maupun orang yang tidak berpendidikan, baik orang kaya, sederhana, dan kurang mampu, baik pemimpin agama maupun orang yang tidak mengerti agama, baik pendeta/gembala maupun jemaat biasa, pasti pernah jatuh dan terjerumus dalam dosa.

Alkitab juga dengan jelas menyatakan hal yang sama bahwa setiap orang tidak ada yang kebal dengan dosa. Peristiwa kejatuhan manusia pertama dalam dosa yaitu Adam dan Hawa (Kej. 3) membuktikan bahwa manusia sekuat dan sehebat apapun pasti jatuh dalam dosa. Fakta kejatuhan Adam dan Hawa dalam dosa membuktikan bahwa manusia sangat lemah dan terbatas untuk melawan dan menolak dosa. Juga membuktikan bahwa ada kecenderungan yang besar dalam diri manusia untuk melawan perintah Allah yang mengakibatkan dia berdosa. Alkitab memberikan banyak contoh kisah tentang orang-orang yang jatuh dalam dosa, mulai dari pembunuhan, penyembahn berhala, perzinahan, dan masih banyak lagi. Bahkan orang yang melakukan dosa-dosa ini adalah 
orang-orang yang mengenal Allah dan melayani Allah. Kisah-kisah didalam Alkitab membuktikan bahwa didalam sejarah manusia dosa sudah berkuasa dan mencemari manusia disegala zaman dan tempat.

Dalam kisah Alkitab Perjanjian Lama maupun Perjanjian Baru, mengenai orang-orang yang sudah jatuh dalam dosa, mereka semua menyadari bahwa dosa sudah sedemikian mencemarkan sehingga merasa tidak layak dihadapan Tuhan. ${ }^{6}$ Ketika Tuhan memanggil beberapa orang untuk melayani-Nya, selalu mereka merasa tidak layak dihadapan Tuhan, ini membuktikan bahwa dosa sudah sedemikian membuat manusia tidak ada harapan dan tinggal menunggu saat penghakiman.

Begitu juga dengan orang-orang zaman ini selalu merasa tidak layak dihadapan Tuhan. Merasa bahwa dosa sudah sedemikian besar dan tidak mampu menghentikan dosa yang sudah menjadi kecenderungan hatinya. Manusia tinggal pasrah dan terus berdosa tanpa kepastian hidup akan datang.

Jikalau manusia tidak bisa mengalahkan kuasa dosa, maka "upah dosa adalah maut" (Rm. 6:23). Apakah manusia masih memunyai pengharapan? Apakah ada jalan keluar bagi manusia untuk lepas dari kuasa dosa? Apakah melalui agama dan aturan-aturannya dapat menjamin keselamatan manusia dari dosa? Mengapa banyak orang tidak dapat mengenal Allah yang sejati didalam agama? Apakah Allah membiarkan manusia terus dikuasai dosa dan pada akhirnya binasa? Kita akan menjawab pertanyaan-pertanyaan ini disepanjang buku ini.

\section{Metode Penelitian}

Metode penelitian yang digunakan disini adalah metode literatur dengan pendekatan kualitatif yaitu mengumpulkan data kepustakaan dengan mencatat hasil amatan secara akurat dan mengungkapkan implikasi penting penelitian ke dalam pengalaman hidup sebagai orang percaya secara tertulis. Melakukan analisis dalam surat Roma 3:23-24 tentang keterkaitan dosa dan anugerah serta faktanya bagi orang percaya sampai sekarang.

\section{Pembahasan dan Hasil}

\section{Anugerah dan Orang Percaya}

Menurut prinsip Alkitab, semua manusia sudah jatuh dalam dosa. Tidak peduli siapapun didunia ini, baik bangsa Yahudi maupun bangsa-bangsa lain

\footnotetext{
${ }^{6}$ Henry C Thiessen, Teologi Sistematika (Malang: Gandum Mas, 1979), 264.
} 
(yang beragama maupun tidak beragama) bersalah dihadapan Tuhan, dan tidak ada satu pun yang lebih baik dari pada yang lain (Rm. 3:23). ${ }^{7}$

Alkitab dengan jelas memberitahu bahwa anugerah dikaruniakan kepada orang yang tidak layak untuk menerimanya. Menurut H. H. Esser, kata "anugerah" khususnya hen berkonotasi "membungkuk, merendahkan diri," berarti "yang lebih kuat datang menolong yang lebih lemah. ${ }^{8}$ Kalau layak itu disebut upah atau imbalan karenaa sudah mengerjakan sesuatu, mengeluarkan tenaga untuk suatu pekerjaan, maka seharusnya akan mendapatkan gaji. Gaji itu bukan pemberian atau belas kasihan, melainkan hak dan layak untuk diterima. Itu bukan anugerah, itu hak seorang pekerja memperoleh gaji/upah. Tetapi yang disebut anugerah, justru bertentangan dengan konsep upah. Kalau upah diberikan kepada orang yang layak, anugerah diberikan kepada orang yang tidak layak. Anugerah diberikan kepada orang yang tidak mengerjakan apa-apa, tidak memunyai jasa sama sekali. Manusia sangat membutuhkan anugerah Allah, namun Allah tidak berutang anugerah kepada manusia. Itulah natur dari anugerah - bukan suatu utang. Allah seharusnya menghakimi manusia atas dosa-dosanya. ${ }^{9}$ Berbicara tentang anugerah Tuhan, maka harus ingat bahwa karena tidak layak menerimanya, karena tidak bekerja apa-apa, tidak berjasa apa-apa, tetapi Tuhan rela memberikannya. Anugerah diberikan kepada orang yang tidak layak, karena tidak pernah bekerja apa-apa untuk menerima anugerah, tidak berjasa dan tidak punya kualifikasi apapun untuk diberikan anugerah.

Dosa adalah kebalikan dari anugerah. Dosa adalah kejahatan yang dilakukan manusia dengan sadar atau tidak sadar. Dosa adalah kekurangan atau kelemahan manusia yang telah menodai kemuliaan (rupa dan gambar Allah) yang sudah diberikan Tuhan pada waktu manusia diciptakan. Alkitab berkata bahwa Allah telah menciptakan sungguh amat baik (Kej. 1:31), tetapi dunia ini menjadi sangat jahat. Segala kejahatan, pencurian, perampokan, perkosaan, sejak ada VCD/DVD film-film porno, homosex, lesbian, maka pemuda-pemudi sudah lebih cepat mengetahui sex, dan lebih berani berdosa berlipat ganda. Kemajuan teknologi telah membawa kemerosotan moral kepada generasi ini. Tuhan memberikan bijaksana untuk menemukan dan memperkembangkan

\footnotetext{
${ }^{7}$ Warren W Wiersbe, Hidup Bersama Firman Pasal Demi Pasal Seluruh Alkitab RomaWahyu (Yogyakarta: Yayasan Gloria, 2011), 15.

${ }^{8} \mathrm{C}$ Brown, New International Dictionary of New Testament Theology (Grand Rapids: Zondervan, 1979), 116.

${ }^{9}$ Mark Dever, 9 Tanda Gereja Yang Sehat (Surabaya: Momentum, 2014), 121.
} 
teknologi, tetapi manusia menggunakan teknologi untuk menyiarkan pornografi, menyebarkan berita hoaks yang dapat mengakibatkan kebencian, kekerasan, dll. Manusia menjadi begitu berdosa lalu berani melawan Tuhan. Dosa adalah ketidakadilan, kerusakan, kebobrokan, dan kesengajaan melawan semua hukum dan semua dalil.

Di dalam berbuat dosa manusia sudah mengerjakan kejahatan, dan mereka telah menjadi musuh-musuh Allah. Tetapi manusia menerima anugerah diberikan dengan cuma-cuma, diberikan kepada orang yang tidak ada sama sekali jasanya, inilah konsep anugerah dalam Alkitab. Upah yang seharusnya diberikan kepada orang yang mengerjakan kejahatan adalah hukuman, tidak ada sesuatu pun yang bisa diperhitungkan sebagai syarat untuk menerima anugerah.

Dosa dari diri manusia, anugerah dari Allah. Itu sebab kalau menerima anugerah itu bukan jasa manusia, tetapi kalau manusia berdosa itu karena dirinya sendiri. Yakobus (penulis surat Yakobus) adalah hamba Tuhan yang menjelaskan bahwa sumber dosa adalah dari nafsu yang dibuahi (Yak. 1:14-15). Kalau keinginan (nafsu) sudah menggoda, lalu menerima tawarannya, berarti rela dibuahi nafsu. Kalau yang seharusnya manusia ciptaan Allah kembali memuliakan Allah, tetapi manusia tidak mau kembali, manusia menerima tawaran untuk berdosa, maka akhirnya nafsu itu menjadi dosa. Tidak semua keinginan itu salah, tetapi keinginan yang tidak di jalankan dijalur Tuhan itu menjadi bibit dosa. Nafsu yang benar adalah hidup yang menikmati seks dengan pasangannya dalam jalur pernikahan yang sah. Nafsu yang buruk adalah menginginkan persetubuhan dengan orang yang bukan miliknya sebelum menikah. Yakobus mengatakan bahwa manusia berdosa karena digoda oleh keinginannya sendiri, sehingga menja dibibit yang membuahi dosa dalam diri manusia. Nafsu membuahi dosa, akhirnya dosa terjadi, langsung berkembang, makin matang, akhirnya dosa membawa maut.

Anugerah dari luar yaitu dari Allah, dosa dari dalam dari manusia. Anugerah dari sorga tetapi dosa dari nafsu diri. Dengan sumber yang berbeda ini, maka harus dilihat status yang sama sekali bersifat kualitas sehingga dapat mengetahui bahwa manusia bertanggung jawab atas dosa. Itu sebab Tuhan Yesus mengatakan: jika tidak menyangkal diri, dan memikul salib maka tidak layak mengikut Tuhan dan menjadi murid-Nya (Luk. 9:23). Jangan mengaku berdosa karena setan. Yang berjudi, berzinah, mencuri, selingkuh, dan sebagainya, bukan setan tetapi manusia itu sendiri. Itu sebabnya Alkitab berkata jikalau manusia mengaku dosanya, maka Allah yang setia dan adil akan mengampuni segala dosa (1Yoh. 1:9). Jikalau konsep ini sudah jelas, baru bisa 
mengerti mengapa Tuhan mau manusia mengaku dosa, dan mengapa Tuhan mau manusia memuliakan Tuhan, karena pada waktu manusia menerima anugerah itu perubahan terjadi dalam dirinya. Ini adalah perubahan besar yang dibutuhkan orang percaya. Pertobatan berarti menyesuaikan hidup dengan Allah dan jalanjalan-Nya, mengakui tuntutan-Nya atas manusia. ${ }^{10}$

Semua orang mengakui bahwa dalam dunia ini banyak kelemahan, banyak kekurangan, banyak rusaknya, sehingga mengetahui bahwa segala sesuatu dalam dunia ini tidak ada yang sempurna, semua sudah dicemari oleh dosa. Jikalau dunia ini sempurna, maka manusia tidak mengeluh, tidak menangis, tidak patah hati, tidak masuk rumahsakit, tidak mengalami kebutaan, tidak mengalami putus asa. Justru dunia ini kurang baik, kurang sempurna, tidak memuaskan, sehingga ada yang putus asa, ada yang gila, ada yang lemah saraf, ada yang bunuh diri dengan loncat kedalam laut, gantung dengan tali, atau minum obat keras. Semakin banyak orang kecewa dengan keadaannya, orang yang bunuh diri makin banyak. Sekalipun di negara maju, teknologi tinggi, ekonomi tinggi, uang banyak, justru disana lebih banyak orang yang merasa hidup tidak berarti apa-apa, akhirnya bunuh diri. Manusia harus mengaku, harus menerima fakta bahwa dunia ini tidak sempurna oleh karena sudah dicemari oleh dosa.

Sebagai contoh beberapa gereja disekitar, awal-awal membuka gereja banyak yang masuk dan mereka dibaptis, tetapi pada akhirnya banyak yang melarikan diri. Ada orang pada waktu kecil suka sekolah minggu, tetapi setelah dewasa tidak mau lagi ke gereja bahkan meninggalkan kekristenan. Ada orang yang dahulu melayani Tuhan seperti sungguh-sungguh, tetapi sekarang tidak mau lagi melayani. Mengapa bisa terjadi demikian? Kebanyakan orang menjawab karena kecewa kepada Tuhan. Inilah jawaban yang sering diberikan oleh orang-orang yang sudah jauh dari persekutuan dengan Tuhan. Apakah pantas manusia (ciptaan) berhak kecewa kepada Tuhan (pencipta)? Mengapa manusia kecewa kepada Tuhan? Jawabanya dari pertanyaan ini adalah manusia tidak pantas kecewa kepada Allah, kalaupun disebabkan oleh karena mengenal Tuhan secara salah, mengerti Allah melalui janji yang salah, pengajaran tentang Allah yang salah.

Roma pasal 6 Paulus mengurus masalah penyalahgunaan kebebasan dan mengingatkan mereka bahwa ketika mereka dibaptis mereka menyadari bahwa

${ }^{10}$ Ibid., 124. 
dosa tidak lagi berkuasa atas mereka. ${ }^{11}$ Ketika seseorang menerima pengajaran yang salah tentang Allah, misalnya ada seorang hamba Tuhan yang terlalu cepat menjanjikan hal-hal tertentu kepada jemaat yang tidak dikatakan firman Tuhan, bukan perkataan dari Tuhan (menjadi orang kristen itu pasti kaya, pasti sembuh, tidak ada kesulitan, semua baik-baik saja, dan sebagainya) sehingga yang mendengar/jemaat mendapat kesan bahwa Tuhan itu murah hati, begitu berkuasa, begitu ajaib. Asal ikut Tuhan, percaya Tuhan, jadi orang kristen, semua beres. Asal berdoa dalam namaYesus, pasti semua persoalan beres. Setelah mendengar pengajaran demikian, jemaat mulai menggebu-gebu, bersungguh-sungguh, berapi-api kepada "Tuhan" yang konsepnya salah. Dan pada akhirnya, Tuhan yang sejati tidak akan melakukan sesuatu hanya karena manusia kira Tuhan harus dan pasti lakukan. Tuhan tidak akan berkompromi kepada orang-orang yang seperti itu. Maka dari situlah manusia menjadi kecewa.

Tuhan mau supaya manusia mengenal-Nya melalui jalur yang benar, dengan pengertian firman yang sejati, dan dengan konsep yang murni dihadapan Allah sehingga seumur hidup kita tidak perlu dan tidak akan kecewa. Manusia tidak perlu kecewa kepada Tuhan, karena sebenarnya tidak ada hal yang perlu dikecewakan manusia kepada Tuhan. Waktu kecewa kepada Tuhan, mengeluh, menangis, setelah itu tetap harus bernafas untuk hidup dan mengeluh lagi, manusia tidak sadar bahwa nafas itu tetap diberikan oleh Tuhan. Ketika menangis, menarik nafas untuk menangis lagi, Tuhan tetap berikan oksigen untuk bernafas. Ketika memukul dada, begitu sedih, selesai itu tertidur karena lelah, waktu itu juga perlu diberikan kekuatan untuk istrahat dari Tuhan. Manusia kecewa kepada Tuhan, kemungkinan karena salah mengerti siapa Tuhan yang sejati, salah mengerti janji Tuhan yang sejati, salah mengerti firman Tuhan yang sejati. Sebagai orang yang percaya Tuhan yang sejati, tidak perlu terpengaruh dengan konsep-konsep tentang Tuhan yang salah tersebut.

Ketika seseorang merasa kecewa kepada Tuhan, muncul pertanyaan: Mengapa Tuhan membiarkan dunia ini begitu banyak penderitaan? Sebelum menjawab pertanyaan ini, perlu mengajukan pertanyaan-pertanyaan lain yang sekaligus juga memberikan jawaban dari pertanyaan itu: Apakah penderitaan yang ada itu tidak berarti apa-apa? Apakah penderitaan tidak ada maknanya? Apakah penderitaan itu tidak bernilai? Apakah manusia yang tidak pernah menderita lebih baik dari orang yang pernah menderita? Ini tidak dipikirkan oleh

${ }^{11}$ David Pawson, Membuka Isi Alkitab PB (Jakarta: Yayasan Indonesia Cahaya Rahmat Empati, 2019), 328. 
orang-orang yang sudah dikuasai oleh kekecawaan, pikirannya menjadi sempit. Sebagai contoh, mengapa orang yang waktu kecil banyak menderita (kekurangan berbagai materi), namun waktu tua lebih bahagia? Sebaliknya, mengapa orang yang waktu kecil terlalu disayang, dimanja dan semua yang ia perlukan dipenuhi, namun waktu tua sangat sulit, sedikit sakit saja sudah mengeluh? Penderitaan-penderitaan yang dialami ada baiknya, ada nilainya yaitu untuk membangun jiwa, membina iman, mengolah karakter. Seseorang yang tidak mempunyai daya tahan yang lama, itu karena tidak pernah mendapat kesempatan untuk menanggung kesulitan, kekurangan, tidak bisa beradaptasi dengan lingkungan dimana saja. Penderitaan itu indah. ${ }^{12}$

Tidak ada suatu daerah yang pernah menghasilkan pemikir paling besar tidak pernah mengalami kesulitan. Orang-orang yang di tempat terlalu enak justru menghasilkan orang-orang yang malas. Daerah-daerah yang serba kecukupan, tidak ada kesulitan menghasilkan banyak orang yang tidak mau berpikir tidak mau berkembang, tidak mau mandiri. Penderitaan menjadi indah, menjadi keharusan bagi orang percaya yang mengerti firman Tuhan dan cara Tuhan bekerja. Tuhan bekerja dalam segala sesuatu yang dialami setiap orang, termasuk tangisan, keluhan, kekecewaan, sakit hati, patah hati, miskin, semua dikerjakan untuk mendatangkan kebaikan bagi orang yang mengasihi Tuhan (Rm. 8:28). Bukan saja demikian, penderitaan itu ada karena dosa sudah melanda dunia. Dosa mengurangi kemuliaan yang Allah berikan dalam diri manusia. Manusia mengeluh karena ada bagian dalam dirinya yang kekurangan. Bagian kekurangan ini yang mengakibatkan manusia tidak mau lagi memuliakan Tuhan, manusia telah berhutang kemuliaan Tuhan. Namun didalam anugerah Tuhan orang percaya kembali menerima apa yang pernah hilang dalam dirinya.

\section{Anugerah dan Pelayanan}

Konsep pelayanan orang percaya adalah berdasarkan anugerah Allah, orang-orang berdosa dipertobatkan, orang-orang fasik diperdamaikan dengan Allah, orang-orang yang tidak benar dibenarkan. ${ }^{13}$ Percaya bahwa pelayanan kepada Tuhan adalah respon ucapan syukur setelah menerima anugerah dari Allah. Sehingga dengan menyadari bahwa segala pelayanan yang dilakukan hanya karena anugerah Allah, berarti di dalam pelayanan, tidak ada lagi tempat bagi ambisi pribadi. Kalau melihat zaman sekarang ini, banyak gereja

\footnotetext{
${ }^{12}$ Aplikasi dari penafsiran surat Ibrani 12:5-11, mengenai identitas dan proses yang harus di alami orang percaya.

${ }^{13}$ Baan, TULIP : Lima Pokok Calvinisme, 6.
} 
(pendeta/gembala) saling berebut jemaat (curi domba), apa lagi kalau jemaat punya banyak uang dengan tujuan untuk memperkaya diri mereka sendiri, bahkan dengan cara-cara yang tidak etis. Konsep pelayanan seperti ini jelas bukan yang diajarkan Alkitab.

Berkali-kali, Paulus mengatakan disetiap suratnya bahwa hanya melalui anugerah Allah, Paulus boleh melayani-Nya. Sehingga Paulus tidak pernah berambisi menyaingi Petrus, Yohanes, dan rasul-rasul yang lain. Didalam 1Korintus 3:6, Paulus memaparkan "Aku menanam, Apolos menyiram, tetapi Allah yang member pertumbuhan." Paulus juga mengajarkan tentang konsep satu tubuh dalam Kristus yang saling menolong dan melayani bersama dalam Kristus (1Kor. 12).

Stephen Tong pernah mengajar satu prinsip yang bagus sekali bahwa tidak ada orang yang datang untuk membantu Tuhan, tetapi semua orang pilihan yang sudah diselamatkan datang untuk melayani dan belajar bersama dalam pekerjaan Tuhan. ${ }^{14}$ Tuhan tidak perlu dibantu oleh manusia, kalaupun Tuhan mau bias mengerjakan sendiri, tetapi ketika Tuhan mengizinkan orang-orang pilihan melayani-Nya, itu adalah semata-mata anugerah Allah. Sudahkah melayani Allah dengan konsep anugerah, bukan dengan konsep ambisi pribadi untuk mencari keuntungan? Didalam kehidupan rohani dan pelayanan, biarlah konsep ini menjadi pelajaran berharga. Ketika mau melayani Tuhan baik di gereja maupun di dunia sekuler, harus diingat satu prinsip: pelayanan adalah anugerah Allah. ${ }^{15}$

Harus menyadari bahwa melayani Tuhan sebenarnya dalam ketidak layakan. Paulus mengajarkan bahwa umat pilihan dibenarkan dan diselamatkan bukan karena perbuatan baik yang dikerjakan, tetapi hanya melalui anugerah Allah dalam iman kepada penebusan Kristus (Rm. 3:24; Ef. 2:8-9). Karena jasa baik manusia itu dipandang sia-sia oleh Allah. Tetapi dunia akan segera melawan konsep yang Alkitab ajarkan ini. Terlalu banyak tawaran dunia mengancam Kekristenan terutama dari psikologi yang ditambah "Gerakan Zaman Baru" lalu mengajarkan prinsip-prinsip bahwa jangan pernah membicarakan diri ini tidak layak, tetapi bicarakanlah dan doronglah orang dengan kata-kata positif, misalnya, "Kamu bisa", "Kamu dahsyat" (berpikir positif).

${ }^{14}$ Stephen Tong, "Mati Terhadap Dosa, Hidup Dalam Kebenaran,” Ringkasan Khotbah Mimbar Reformed Injili, 1994.

${ }^{15}$ Aplikasi dari penafsiran Surat Kolose 3:17\&23 mengenai etos kerja Kristen. 
Tidak heran, di dunia postmodern ini, muncullah pikiran-pikiran bahwa apa yang dipikirkan itu yang didapatkan. Pengajaran ini juga sudah memengaruhi orang-orang kristen, sering kali orang kristen mengatakan, "Dimana ada kemauan, disitu ada jalan" bahkan ada dalam bentuk lagu rohani. Semuanya mengajarkan bahwa asal ada keinginan, semua pasti berhasil. Yang lebih celaka, pelatihan seperti ini diimpor dan diajarkan oleh gereja. Hal ini juga diadopsi di dalam konsep pelayanan "Kristen".

Di zaman sekarang ini terdapat begitu banyak orang Kristen yang melayani dengan konsep kehebatannya sendiri, membantu pelayanan sana sini, berfasih lidah dalam berkhotbah, pintar dalam berorganisasi, dan sebagainya, sehingga yang ditonjolkan dalam pelayanan adalah dirinya yang hebat. Inilah realita dunia yang tidak mau menerima kenyataan negatif yaitu ketidaklayakan. Kekristenan yang beres tidak boleh mengikuti apa kata dunia, tetapi apa kata Alkitab. Kenyataan negatif yang mengajarkan bahwa orang percaya tidak layak bukan dengan tujuan melemahkan semangat dalam pelayanan, tetapi justru berfungsi dua hal: pertama, untuk menyadarkan realita yang sebenarnya yaitu benar-benar tidak layak, karena telah berdosa dan mengalami kerusakan total. Sekaligus, kedua, untuk mendorong pelayanan yang tidak berfokus pada kehebatan diri kita sendiri, tetapi kepada Allah yang memimpin dalam melayani-Nya. Dengan semakin memandang ketidaklayakan, maka semakin terus bergantung mutlak/penuh kepada-Nya.

Jika Tuhan sudah memberikan talenta dalam berbagai hal dapat dikerjakan, maka waktu kembali kepada-Nya, Tuhan akan menilai, sudahkah menggunakan talenta itu dengan setia? Maka anugerah bukanlah sesuatu yang membuat orang percaya merasa bangga dan membawa pada kesombongan, karena harus mempertanggung jawabkannya kepada Tuhan. Oleh sebab itu, orang yang mempunyai banyak talenta harus lebih gentar dari pada orang yang mempunyai lebih sedikit talenta. Orang yang mempunyai lebih banyak karunia harus lebih berhati-hati dari pada orang yang karunia dan bakatnya lebih sedikit. Orang yang mempunyai kesempatan, kebebasan, kepintaran, uang yang lebih banyak harus lebih berhati-hati dari pada orang yang mempunyai uang lebih sedikit. Karena kepada yang diberi banyak akan dituntut lebih banyak, kepada yang diberi sedikit akan dituntut lebih sedikit. Inilah prinsip keadilan di hadapan Tuhan Allah. 


\section{Anugerah dan Relasi Pribadi Dengan Allah}

Alkitab mengajarkan bahwa hal mengenal Allah sesungguhnya merupakan hal yang tidak mungkin bagi manusia semenjak kejatuhan dalam dosa. Maka relasi kembali antara Allah dengan manusia setelah jatuh dalam dosa hanya mungkin terjadi jikalau Allah sendiri yang menghampiri manusia dan menciptakan lagi relasi yang baru. Itulah yang dicatat dalam Alkitab, Allah mau lagi menghampiri Adam dan Hawa dan terus berelasi dengan manusia, namun Alkitab mencatat, justru yang terjadi adalah kejatuhan demi kejatuhan dalam dosa dialami oleh keturunan Adam hingga hari ini. Dampak dosa begitu besar sehingga begitu merusak hidup manusia dan membuat manusia tidak dapat kembali kepada Allah dan bahkan tidak ada manusia yang mencari Allah dalam arti yang sesungguhnya (Rm. 3).

"Sebab semua orang telah berbuat dosa dan telah kehilangan kemulian Allah" (Rm. 3:23). Ini bersifat universal di antara semua suku-suku dan bangsa diseluruh dunia. Betapapun terbelakangnya suatu bangsa atau suku bangsa, semua manusia dimanapun berada terus menerus mengaku akan hal ini, bahwa telah berdosa di hadapan Allah. Maka manusia mulai mencari jalan keluar, mulai menciptakan agama dan berusaha untuk mengenal Allah, namun semua usaha manusia untuk mengenal Allah yang sejati, walaupun hal itu adalah ketidakmungkinan. Itulah gambaran sesungguhnya yang dilakukan oleh semua manusia di muka bumi ini ketika mencoba mengenal Allah. Pada dirinya sendiri manusia tidak akan pernah mengenal Allah atau bertemu dengan Allah yang sejati. Sehingga semua usaha manusia untuk menciptakan agama sesungguhnya adalah kesia-siaan untuk dapat bertemu dan mengenal Allah. ${ }^{16}$

Tidak mengherankan juga, entah itu di gereja, di kuil-kuil, orang-orang mengadakan upacara, mengadakan ritual-ritual dengan tujuan agar memperoleh penyucian dari dosa-dosanya. Kutuk dosa dirasakan oleh semua orang, jiwa yang berdosa itu harus mati, karena upah dosa ialah maut (Rm. 6:23). Setiap orang tidak mungkin dapat lari dari penghakiman akan dosa. Tetapi manusia sering kali melarikan diri dari kenyataan dirinya yang berdosa dengan menutupi dosanya dan menyalahkan orang lain. Itulah yang mengkarakteristik manusia yang adalah keturunan Adam. Adam berkata: "Perempuan yang Kau tempatkan di sisiku, dialah yang memberi dari buah pohon itu kepadaku, maka kumakan." (Kej. 3:12). Dan kemudian perempuan itu berkata kepada Tuhan Allah, "Ular itu yang memperdayakan aku maka kumakan.”(Kej. 3:13). Sejak hari kejatuhan

${ }^{16}$ Firman Panjaitan, "Dialog Imajiner Kaum Tertindas: Tafsir Kejadian 3:1-6 Dalam Konsep Carnivalesque Bakhtin,” Kenosis: Jurnal Kajian Teologi 6, no. 1 (2020): 1-22. 
manusia yang begitu tragis itu, manusia semua selalu mencoba untuk menyalahkan orang lain atas kesalahan-kesalahannya. Orang yang telah dinyatakan bersalah seringkali mengelak dan tidak mengakui kesalahannya. Manusia seharusnya mengakui dosa-dosanya sendiri dan harus bertanggung jawab untuk menerima penghakiman dari Tuhan. Namun, seringkali manusia berusaha untuk menyembunyikan segala dosa dan kesalahan di tempat yang tersembunyi supaya tidak seorangpun mengetahuinya.

Melakukan upacara atau ritual-ritual adalah satu usaha untuk menyembunyikan dosa-dosa. Namun walaupun tersembunyi, tidak akan mengubah warna dosa dihadapan Allah dan tidak dapat menghindarkan diri dari penghakiman Allah yang sangat mengerikan. Firman Allah berkata bahwa Tuhan mengetahui setiap hati manusia dan mengenal setiap jiwa manusia.

Manusia tidak dapat menghapus dosa-dosanya, tidak dapat menyelamatkan diri sendiri, tidak dapat membersihkan noda pelanggaranpelanggaran dan kejahatan sendiri, apa yang harus manusia lakukan? Allah yang mahakasih mau menyatakan pengampunan bahkan penebusan didalam kedatangan Yesus Kristus kedalam dunia membuka kembali kemungkinan bagi manusia untuk mengenal Allah dan bersekutu dengan Allah. Pengertian ini dilihat dari sudut pandang Alkitab, penyebab yang menggerakkan penebusan sesungguhnya adalah kehendak Allah. ${ }^{17}$ Allah yang berkehendak untuk menyelamatkan orang berdosa dengan suatu korban penebusan yang menggantikan manusia (Yoh. 3:16). Oleh sebab itu, orang Kristen harus menurut teladan Kristus melakukan hal-hal yang dilakukan oleh Kristus (1Yoh. 2:6). Orang Kristen juga di sebut "Orang Kudus" dikuduskan oleh Kristus. ${ }^{18}$ Ini adalah berita Injil dari anugerah tentang Anak Allah. Itu disebut kabar baik, bahwa dalam Kristus ada kesembuhan, ada keselamatan dan ada pengampunan dari segala kejahatan. Yesus berkata ini adalah darah-Ku darah Perjanjian Baru yang dicurahkan untuk penyucian manusia dari dosa (Mat. 26:28; Mrk. 14:24).

Pengalaman pertama yang pernah dialami semua orang percaya, yaitu ketika menjelaskan tentang pertobatan, yaitu ketika berjumpa dengan Tuhan Yesus dan menerima-Nya sebagai Tuhan dan Juruselamat pribadi. Irish V. Cully, percaya bahwa hidup di hadapan Allah menolong seseorang untuk memilki sesuatu kehidupan yang selaras dengan Tujuan Allah bagi dirinya dan

${ }^{17}$ Charles M. Horne, Salvation (Chicago: Moody Press, 1971), 15.

${ }^{18}$ Warren W Wiersbe, Buku Pedoman Katekisasi Di Atas Dasar Yang Teguh (Malang:

Sinode GKT, 1995), 90. 
dunia ini. ${ }^{19}$ Walaupun memiliki cara yang berbeda dalam menyaksikan akan pertobatan itu, tetapi ada satu pengalaman yang pasti semua alami dan itu adalah apa yang telah dilakukan Allah melalui Kristus untuk mengampuni manusia dari dosa. Alkitab menjelaskan kebaikan Allah ini kepada manusia seperti dalam Mazmur 103, "Ia berfirman, Sejauh timur dari barat demikian dijauhkannya manusia dari pelanggaran,". Dalam Yesaya 44, berkata bahwa "Allah telah menghapuskan segala dosa pemberontakanmu seperti kabut yang diterbangkan angin dan sekarang dosamu seperti awan yang tertiup. Dan setelah dosamu seperti awan yang tertiup kembalilah kepada-Ku sebab Aku telah menebus engkau!" Dalam Hosea 14, berkata bahwa "Roh Allah telah melemparkan dosadosamu kedalam samudera." Itulah sebabnya ada sesuatu di dalam iman Kristen yang tidak mungkin ditemukan dalam agama-agama lain.

Inilah yang telah Allah lakukan bagi manusia. menyelamatkan, menyucikan dan menjadikan putih seperti salju. Biarlah setiap orang percaya senantiasa memuji, memuliakan dan mengucap syukur kepada Tuhan Yesus yang telah memberikan anugerah yang besar bagi manusia. Satu-satunya yang dapat menyelamatkan manusia adalah Juruselamat Agung, yang telah menghadapi dan menerima penghakiman Allah karena menanggung dosa-dosa dan kesalahan-kesalahan manusia. Yesus telah menggantikan manusia yang seharusnya dihukum atas dosa. Tuhan menebus dan menyelamatkan manusia melalui anugerah-Nya. Sehingga orang berdosa melalui penebusan masuk kedalam hadirat Allah. Orang percaya telah disucikan dan dibersihkan di dalam darah Anak Domba, penasehat ajaib, sahabat sejati, mediator manusia, perantara, yang akan mendampingi pada hari penghakiman. Ketika mempelajari Surat Roma, menemukan penjelasan tentang keselamatan tiga masa: masa lalu, masa kini, dan masa depan. ${ }^{20}$ Stedman menjelasakan, masa lalu: kita telah diselamatkan ketika percaya kepada Yesus; masa kini: sedang diselamatkan ketika karakter Yesus Kristus kini menjadi nyata dalam kehidupan; masa depan: akan diselamatkan ketika pada akhirnya, dalam kehidupan kebangkitan, dengan tubuh yang dimuliakan.

Orang percaya yang telah menerima anugerah Allah masih mempunyai kemungkinan bisa jatuh didalam dosa. Meskipun orang Kristen masih berada

${ }^{19}$ Warren W Wiersbe, A Practical Teology of Spirituality (Grand Rapids: Zondervan, 1987), 13.

${ }^{20}$ Ray C Stedman, Petualangan Menjelajahi PB (Jakarta: PT. Duta Harapan Dunia, n.d.), 103. 
dalam dunia ini, tetapi ia tidak hidup untuk dunia ini. ${ }^{21}$ Perbedaannya adalah orang-orang berdosa yang telah ditebus tahu memiliki kepekaan yang besar terhadap dosa dan memerlukan Kristus. Orang percaya harus selalu bersandar pada Kristus dan bukan pada diri sendiri, dengan demikian dapat menghindari perangkap-perangkap yang menjerat untuk berdosa. Orang percaya dipanggil untuk menerangi dan menggarami dunia yang memunyai tanggung jawab di hadapan Allah.

Memiliki anugerah memunyai tanggung jawab yang lebih besar. Tanggung jawab orang Kristen sangat besar dan berat, sehingga menjadi orang Kristen merupakan sebuah kesengsaraan sekaligus sukacita. Sengsara karena harus memikul salib, bersukacita karena Tuhan beri keselamatan. Sebab itu orang Kristen harus mengorbankan tenaga, waktu, semangat, kepandaian, harta, bahkan seluruh hidupnya untuk memberitakan Injil. ${ }^{22}$ Memikul salib karena harus menolak dosa, mematikan kedagingan, tidak serupa dengan dunia. Pikul salib juga berarti luas, misalnya menanggung beban yang mungkin itu di sebabkan oleh orang lain yang tidak sepaham, menerima hidup baik suka sekaligus duka, menguasai bidang yang dituntut oleh standar hidup. Setiap orang yang mengaku Kristen tetapi hidup lebih rendah dan lebih buruk dari orang bukan Kristen hanya akan menghina Kekristenan itu sendiri.

Kenapa orang percaya gagal mempengaruhi orang lain? Hal ini disebakan karena gagal merepresentasikan iman kepada orang lain. Orang percaya tidak lebih baik dari orang lain, tidak lebih berintegritas. Malah hanyut dan bahkan kadang lebih buruk dari orang diluar Kristus. Orang yang hidupnya sembarangan tidak akan punya pengaruh apa-apa. Setuju atau tidak, jika orang percaya tidak memikul salib mustahil akan membawa terang pada dunia ini. Orang percaya harus menghargai anugerah Tuhan dan mengerjakan panggilan Kekristenan. Menghargai anugerah pasti menyadari betapa besar anugerah Tuhan dalam hidupnya. Hidupnya pasti menghasilkan buah yang baik yang disertai perbuatan-perbuatan baik, karena iman tanpa perbuatan hakekatnya adalah mati (Yak. 2:26).

Segala sesuatu yang ada pada manusia merupakan anugerah, seperti harta, kesehatan, kepandaian, pekerjaan, dan masih banyak lagi, merupakan titipan dari Tuhan, maka harus dipergunakan dengan bijaksana dan bertanggung jawab tidak boleh berbuat sembrono dengan anugerah yang sudah Tuhan berikan. Ketika orang masih sehat maka tidak pernah menyadari betapa berharganya

\footnotetext{
${ }^{21}$ Wiersbe, Buku Pedoman Katekisasi Di Atas Dasar Yang Teguh, 91.

${ }^{22}$ Ibid., 93.
} 
anugerah kesehatan yang Tuhan berikan dan orang baru menyadari betapa berharganya kesehatan ketikasudah sakit. Orang yang sadar bahwa semuanya adalah anugerah Tuhan, maka tidak berani bermain-main dengan anugerah Tuhan. Dengan demikian, Tuhan ingin melatih dan mendidik setiap orang percaya yang menyadari akan anugerah Tuhan yang besar, untuk bisabertanggung jawab dalam melakukan segala sesuatu dengan semangat yang rendah hati di hadapanTuhan maka hidup akan menjadi lebih indah.

\section{Simpulan}

Dari pemaparan diatas dapat disimpulkan bahwa orang percaya harus mengerti mengenai anugerah Tuhan. Mempelajari dan mengerti Anugerah Tuhan dapat memberikan jawaban bagi orang yang tidak memiliki jawaban. Alkitab mengajarkan bahwa anugerah yang diberikan kepada manusia dikerjakan dengan pembayaran harga yang paling mahal yaitu darah Anak Tunggal Allah sendiri. Alkitab mengatakan harganya dibayar bukan dengan emas dan perak tetapi dibayar dengan darah Anak Domba Allah (Yoh. 3:16; IPet. 1:18). Anugerah yang Allah berikan adalah merupakan ungkapan cinta kasih yang tidak ada ukurannya diseluruh dunia. Dengan mengerti anugerah Allah maka membawa orang semakin menghargai dan meresponi anugerah tersebut dengan sikap takut akan Tuhan. Setelah menyadari pentingnya mengerti anugerah, maka penulis yakin bahwa jika konsep anugerah diajarkan dengan baik dan benar, maka orang percaya akan semakin memahami bahwa anugerah adalah murni pemberian Allah yang sangat berharga.

\section{Daftar Pustaka}

Baan, G. J. TULIP : Lima Pokok Calvinisme. Surabaya: Momentum, 2017.

Barth, Christoph. Teologi Perjanjian Lama 1. Jakarta: BPK GunungMulia, 2010. Berkhof, Louis. Teologi Sistematika Vol. 1: Doktrin Allah. Surabaya: Momentum, 2008.

Brill, J.Wesley. Dasar Yang Teguh. Bandung: YKH, 1996.

Brown, C. New International Dictionary of New Testament Theology. Grand Rapids: Zondervan, 1979.

Charles M. Horne. Salvation. Chicago: Moody Press, 1971.

Cully, Iris V. Dinamika Kristen. Jakarta: BPK Gunung Mulia, n.d.

Dever, Mark. 9 Tanda Gereja Yang Sehat. Surabaya: Momentum, 2014.

Panjaitan, Firman. "Dialog Imajiner Kaum Tertindas: Tafsir Kejadian 3:1-6 Dalam Konsep Carnivalesque Bakhtin.” Kenosis: Jurnal Kajian Teologi 6, 
Implikasi Praktis Konsep... (Jetorius Gulo)

no. 1 (2020): 1-22.

Pawson, David. Membuka Isi Alkitab PB. Jakarta: Yayasan Indonesia Cahaya Rahmat Empati, 2019.

Stedman, Ray C. Petualangan Menjelajahi PB. Jakarta: PT. Duta Harapan Dunia, n.d.

Thiessen, Henry C. Teologi Sistematika. Malang: Gandum Mas, 1979.

Tong, Stephen. "Mati Terhadap Dosa, Hidup Dalam Kebenaran." Ringkasan Khotbah Mimbar Reformed Injili, 1994.

Wiersbe, Warren W. A Practical Teology of Spirituality. Grand Rapids: Zondervan, 1987.

—. Buku Pedoman Katekisasi Di Atas Dasar Yang Teguh. Malang: Sinode GKT, 1995.

. Hidup Bersama Firman Pasal Demi Pasal Seluruh Alkitab RomaWahyu. Yogyakarta: Yayasan Gloria, 2011. 